\title{
Meaning of Phrasal Verb 'pick up' Subtype do/happen: A Natural Semantic Metalanguage Approach
}

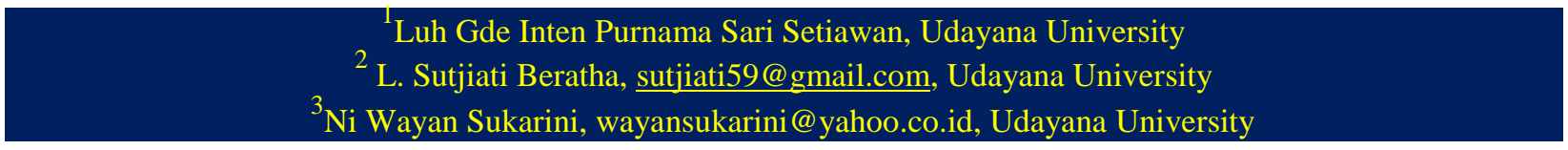

*Corresponding Author: girlsactive88@gmail.com

Received Date: 10-01-2019 Accepted Date: 28-02-2019 Published Date: 31-07-2019

Abstract-The difficulties in knowing and understanding the meaning of a language often appear in units of language with an idiomatic meaning, such as phrasal verb. A single unit of phrasal verb usually produces a meaning which is totally different with the meaning of its constituent. Phrasal verb 'pick up' is a unique phrasal verb since it bears various meanings unlike other phrasal verbs. The implementation of Natural Semantic Metalanguage (NSM) as a theory in this study leads to a great significance of avoiding misunderstanding on the meanings of phrasal verb 'pick up' by defining the meanings through semantic structures. This study is intended to find and describe the meanings of phrasal verb 'pick up'. Mention the object of the study here result of this study showed that phrasal verb 'pick up' is a kind of transitive phrasal verb which often followed by object. The different objects in phrasal verb 'pick up' lead to noncomposition polysemi between DO / HAPPEN. This combination of two polysemies come in eight meanings.

Keywords: phrasal verb, pick up, Natural Semantic Metalanguage

\section{Introduction}

The complexity of meaning produced in a language can be influenced by the presence of cultural and environmental features that creates difficulty in understanding meaning contained. Difficulties in knowing and understanding the meaning of a language usually appears in units of language that have special meanings in the form of idiomatic meaning. The meaning cannot be predicted by translating it literally. Furthermore, languages are different from one to another syntactically, or perhaps semantically (Utami et al, 2018:1). Semantically, phrasal verb is a phrase that contains idiomatic meanings and it cannot be predicted easily by finding the meaning of each lexicon. Idiomatic meanings are often related to the environment, culture and it is a form of the naturalness of languages made by their native speakers. As stated in Sumitri's study (2015), language is a container in which the meaning lists conceptualization of culture that includes an overview perspective of community groups citizens concerned to the world.

The strong relation between idiomatic meanings with native speakers is shown by the 
frequency of phrasal verb used in every day's people life both in written and spoken English. This is supported by Altenberg (1998: 45) which states that "the lexicon of adult native speakers may consist of up to 80 percent of such phraseological units". Besides, Fletcher (2005: 78), also states that phrasal verb is something that is typical of English and is widely used in written and formal and informal English.

Therefore, according to this, non-native speakers will find very high intensity in the use of phraseology units, such as phrasal verb. This high frequency of using phrasal verb suggests a linear relationship with the non-native speaker's understanding of the meaning. A misunderstanding in the meaning of phrasal verb can lead speaker to misunderstanding of the whole message conveyed in an expression or a text.

According to a study conducted by Ryoo (2013), the verb 'pick' is one of the most widely used verbs as phrasal verb proven in the BNC (British National Corpus) corpus data-based study. A combination between verb 'pick' and particle 'up' appeared 9037 times, as well as particles 'out' 856 times, particles 'on' 35 times and particles 'back' 3 times. The high appearance of combination between verb 'pick' and particle 'up' may occur since it has a number of meanings that are different from the meaning of each lexicons.

Some of the following sentences use phrasal verb pick up

(1-1) Let's pick up where we left off yesterday. (Kinsella, 2004: 36)

'to continue'

(1-2) Did you pick up on the thing I've said before? (Kinsella, 2004: 74)

'to give attention'

(1-3) I need to pick something up at the drug store (Kinsella, 2010: 88)

'to buy'

(1-4) She said something I couldn't hear, then bent down to help pick up the papers.

(Kinsella, 2011: 213)

'to take something from the ground'

Phrasal verb 'pick up' has an ability to produce more than one different meanings. Phrasal verb was previously limited to certain meanings, but during period of time a language can change according to the environment. Thus, the new meanings exist in several non-formal context and situation. Those different meanings cause confusion to the non-native speakers. In relation to

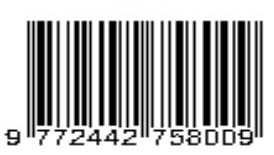


this, the objective of this study is to find and describe the different meanings that may occur in sentences consist of phrasal verb 'pick up' through semantic structure.

The meaning of a word or phrase in certain language should be transferred precisely to the target language by including an understanding of the small things related to the word / phrase itself. Thus, this study needs an approach to find out the implicit meaning in the phrasal verb pick up. Natural Semantic Metalanguage (NSM) approach is able to describe each of the smallest components present in the phrasal verb through a set of semantic primes, along with noncomposition polysemy and universal syntax of meaning.

\section{Research Methods}

This research is a qualitative descriptive study because the findings are not obtained through statistical procedures or other forms of calculation (Strauss, 2003: 7). Provision of large amounts of phrasal verb pick up data is collected from informal conversations found in novels by Sophie Kinsella. The data was collected through observation and note-taking. After the data was taken, then the data was analysed based on distributional method since it is a method that makes the part of the language a decisive tool. The determinant tool in the framework of the distributional method is always clear because it is a part or element of the language of the object of the research itself, such as words (broken words, prepositions, adverbial, etc.), syntactic functions (subject, object, predicate, etc.), clause (syllable, pitch, etc.) (Sudaryanto, 1993: 1819). The technique used to analyse the semantic structure of phrasal verb pick up is the paraphrase technique.

\section{Result and Discussion}

The result of this study found that phrasal verb pick up has 8 different meanings. Those different meaning occurs as a result of different object and the sentence's context of situation. The table bellow shows the meaning in Indonesia and English. 


\begin{tabular}{|lll|}
\hline \multicolumn{1}{|c|}{ Indonesia } & \multicolumn{1}{c|}{ Makna } \\
\hline & memungut & $\begin{array}{l}\text { Inggris } \\
\text { to take hold of something and lift it up from lower } \\
\text { placelgnd } \\
\text { to collect/take something from a place }\end{array}$ \\
& mengambil & to clean and tidy up \\
Phrasal & membereskan & to pay someone's bill \\
$\boldsymbol{V}$ U' 'Pick & membayarkan & to buy \\
& membeli & to arrest \\
& memenjarakan & To get to your feet after fall \\
& bangkit/bangun & To return after something bad \\
& membangun kembali &
\end{tabular}

The difficulties comes when find the appropriate word in Indonesia since these two languages have the different culture and environment. Apart of this, the concern of this study only on the meaning and semantic structure to define the detail meaning of them. The further discussion of those meaning will be explained as followed

\section{a. Pick up 'to take something and lift it up from lower place/ground'}

(1) She said something I couldn't hear, then bent down to help pick up the papers. (Kinsella, 2011: 213)

(2) My baby went down to pick up his hot-wheel on the ground, and the car just passed right by him. (Kinsella, 2013: 213)

The component of meaning to the phrasal verb 'pick up' in the sentence above is the position of the object. The object must be something on the ground or floor. The process that occurs in phrasal verb pick up with the meaning of 'memungut' is a movement made by the subjects which include a part of their body as an effort to reach the object. It can be done by bending the body, squatting, or in a position on one knee. The non-composition polysemy to this meaning is DO/HAPPEN with structure semantic as below:

'to take something and lift it up from lower place/ground',

At one time, $\mathrm{X}$ did something to $\mathrm{Y}$

$\mathrm{X}$ did like this:

I did this with my hand 
I did this in short time

Because of this, body part of $\mathrm{X}$ move down (using hand)

After that, $\mathrm{Y}$ move to $\mathrm{X}$ at the same time

$\mathrm{X}$ want this

$\mathrm{X}$ do like this

\section{b. Pick up 'to collect/take something from a place'}

(1) It doesn't belong to me and I did not pick up your wallet (Kinsella, 2018: 89)

(2) All I've been allowed to do is type out copy, arrange meetings for other people, get the sandwiches and pick up my boss's dry-cleaning. (Kinsella, 2018: 260)

In general, the components the word 'mengambil' have the same semantic features as the word 'memungut' as both of them indicate an action to take something. The different semantic features comes in the form of the object position. The objects in phrasal verb pick up 'memungut' must be something on the ground/floor. However, the objects of phrasal verb pick up 'mengambil' is not limited to certain position. Objects in the word 'mengambil' correlates with everything taken in any position from the subjects. The non-composition polysemy to this meaning is DO/HAPPEN with structure semantic as below:

'to take'

At that time, $\mathrm{X}$ did something to $\mathrm{Y}$

At the same time, Y moves beside $\mathrm{X}$

$\mathrm{X}$ did this with part of $\mathrm{X}$ (hand)

$\mathrm{X}$ did this for a certain time

$\mathrm{X}$ did something like this

\section{c. Pick up 'to clean'}

(1) As I pick up toys and rub the spilled milk out of the rug, I regret that I was very angry to them (Kinsella, 2003: 218)

This meaning will be related to the objects in the form of something scattered on the floor. According to Oxford Phrasal Verb Dictionary, one of the meanings of phrasal verb pick up is "to tidy a room, etc and put them away". This meaning does not have a certain limitation regarding the concept of 'cleaning up' in the sense of tidying up and storing, or tidying and disposing. The most important thing is the event effect that occurs after that, which is a condition of object becomes clean and tidy. The meaning of the word 'membereskan' can be considered as 
a derivation of the meaning of 'cleaning up' or 'membersihkan'. The non-composition polysemy to this meaning is DO/HAPPEN with structure semantic as below:

\section{'to clean'}

At one time, $\mathrm{X}$ did something to $\mathrm{Y}$ (toys, spilled milk)

Because of this, something happened to $\mathrm{Y}$ like:

I did something with body parts (hands)

I did something for some time

$\mathrm{X}$ wants this

$\mathrm{X}$ did something like this

\section{d. Pick up 'to arrest'}

(1) a swanky beach club near St. Tropez, to pick up two drug-dealer who were supposed to be there (Kinsella, 2018: 55)

Phrasal verb pick up can have a meaning of 'to arrest' or 'memenjarakan' with an object must be a criminal (thief, robber, drug dweller, etc.). This action can only be carried out by authorities such as the police. Motivation carried out by the perpetrator of the action is the desire to find the entity and bring it to a place, namely the police station. The noncomposition polysemy to this meaning is DO/HAPPEN with structure semantic as below:

\section{'to arrest'}

At one time, $\mathrm{X}$ did something to $\mathrm{Y}$ (criminal, robber, drug dweller, etc.).)

Something happened to Y like:

$\mathrm{X}$ did something on the part of $\mathrm{Y}$ (hand)

$\mathrm{X}$ did it with something (handcuffs)

At the same time, $\mathrm{X}$ and $\mathrm{Y}$ move to a place (police station)

$\mathrm{X}$ thinks this is true

$\mathrm{X}$ wants this

$\mathrm{X}$ did something like this

\section{e. Pick up 'get up'}

(1) Will he fall down and learn how to pick himself up again on the skating floor. (Kinsella, 2008: 73)

(2) He waited for her to painfully pick herself up when her foot slipped on a mossy rock and she fell (Kinsella, 2018: 290) 
According to the object of the sentence above, it can be ascertained that the objects belong to a reflexive pronoun which states that the action is carried out on its own without the help of others. The pronouns which are entities in the data above are himself and herself with the position of pronouns are between verbs and particles. Phrasal verb pick up with the meaning 'bangun/bangkit' can be said as separable phrasal verb. The meaning of phrasal verb pick up according to the context in the sentence above also has a correlation with the word 'fall'. The non-composition polysemy to this meaning is DO/HAPPEN with structure semantic as below:

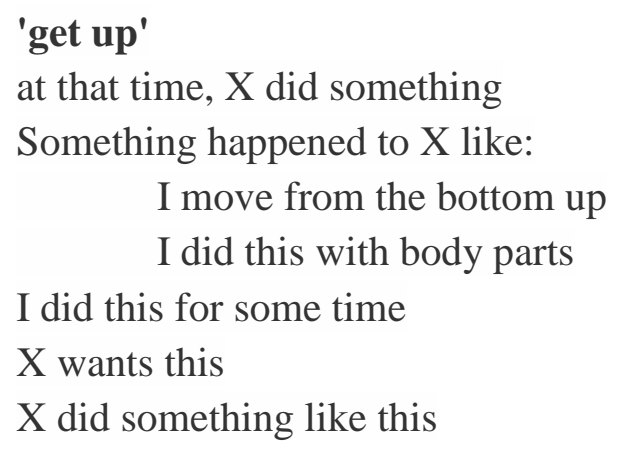

\section{f. Pick up 'to pay someone's bill'}

(1) Then tap the customer on the shoulder, pick up the bill and ask if it belongs to him. (Kinsella, 2018: 240)

The object that become the significance role after phrasal verb pick up with the meaning above is a 'bill' which specified into someone's bill. The semantic component to define the meaning of phrasal verb pick up above is the action result. Someone will get benefit by the subject because someone did something good for him/her. Therefore, the non-composition polysemy to this meaning is DO/HAPPEN with structure semantic as below:

\section{'to pay'}

At one time, $\mathrm{X}$ did something to $\mathrm{Y}$

If something happens like:

I do something for someone

Someone feels this good

I want this

$\mathrm{X}$ can do this

\section{g. Pick up 'return after something bad'}

It was time to pick up the pieces of their lives and try to move on (Kinsella, 2003: 72) 
This meaning is related to something bad happened in the past. The use of phrasal verb pick up also shows that later something good is about to happen, so the subject of the sentence can feel a better condition than before. This can be expressed by the use of natural language in explication such as 'before, $\mathrm{X}$ felt bad, now $\mathrm{X}$ feels something good because $\mathrm{X}$ did this. Therefore, the non-composition polysemy to this meaning is DO/HAPPEN with structure semantic as below:

'return after something bad'

at that time, $\mathrm{X}$ did something

Something happened to $\mathrm{X}$ like:

Before, I felt bad

Now I feel my life is better because I do this

I know this is true

$\mathrm{X}$ wants this

$\mathrm{X}$ did something like this

\section{h. Pick up 'to buy'}

(1) Adam had hospital calls to make but decided to pick up a sandwich at the Subway (Kinsella, 2013: 179)

According to Oxford Learner's' Dictionary, the meaning of phrasal verb pick up for data above is to buy something, especially cheaply or by chance / luck. The characteristic of the objects is something that can be traded. These objects include food, drinks, everything provided in minimarket, café, cofeeshop, etc. The objects are generally not a very highvalue item, however it refer to a basic need of daily activity. Therefore, the noncomposition polysemy to this meaning is DO/HAPPEN with structure semantic as below:

\section{'to buy'}

At that time, $\mathrm{X}$ did something to $\mathrm{Y}$ (food, drinks)

At the same time, something happened to $\mathrm{Y}$

If $\mathrm{Y}$ experienced something like:

I move closer to $\mathrm{X}$

$X$ feels it's good

$\mathrm{X}$ did it because he wanted me

$\mathrm{X}$ can do this 


\section{Conclusion}

The result of this study showed that phrasal verb pick up is a kind of transitive phrasal verb which often followed by object. It was also shown that there are eight different meaning of phrasal verb pick up in the category of polysemy between DO/HAPPEN. The difference in meaning can be very diverse due to the differences in direct objects that follow the phrasal verb. Some meanings of phrasal verb 'pick up' require that the pronoun object must be in the position between the verb and the particle. The semantic structure is formed through paraphrase by using semantic primes leads to a clear simple description of each phrasal verb 'pick up' meaning.

\section{References}

Altenberg, B. 1998. On The Phraseology of Spoken English: The Evidence of Recurrent Word combinations. In A. P. Cowie (Ed.), Phraseology: Theory, analysis and Applications (pp. 101-122). Oxford: Clarendon Press.

Fletcher, B. 2005. Register and Phrasal Verbs. MED Magazine. The Monthly Webzine of McMillan English Dictionaries, 33, 45-54.

Goddard, C. 1996. "Building a Universal Semantic Metalanguage" the Semantic Theory of Anna Weirzbicka' dalam C. Goddard (ed) 1996. Cross Linguistic Syntax from a

Semantic Point of View (NSM Approach). Canberra: Australian National University.

Quirk, Pandolf and Sidney Greenbaum. 1975. A University Grammar of English. London: Longman Group Limited

Strauss dan Corbin J. 2003. Dasar-Dasar Penelitian Kualitatif : Tata langkah dan Teknik- Teknik Teorisasi Data. Pustaka Pelajar, Yogyakarta: Abimanyu, et al.

Sudaryanto. 2015. Metode dan Aneka Teknik Analisis Bahasa. Yogyakarta: Sanata Dharma University Press

Sudipa, I N. 2004. "Verba Bahasa Bali: Sebuah Kajian Metabahasa Semantik Alami (MSA). Disertasi”. Denpasar: Program Pascasarjana, Unversitas Udayana.

Sudipa, I N. 2010. Struktur Semantik: Verba Keadaan Bahasa Bali. Denpasar: Udayana University Press

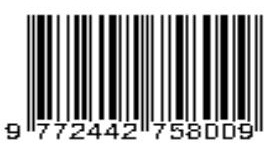


Sumitri, ni wayan et al. Form and meaning of ti'i ka discourse in mbasa wini ritual of rongga ethnic in flores.e-journal of linguistics, [s.1.], jan. 2015. Issn 2442-7586.

Sutjiati Beratha, Ni Luh. 1997. Basic Concept of a Universal Semantic Metalanguage. Linguistika, tahun IV Edisi keenam, 110-115

Utami, I Made Verayanti; Apriliani, Kadek; Sugiarti, Dian Pramita. 10.24843 The Analysis of Indonesian Transitive and Intransitive Verbs Found in the Translation of Possum Magic - An Australian Classic by BIPA Students of La Denpasar. e-Journal of Linguistics, [S.1.], v. 12, n. 2, p. 79-87, july 2018. ISSN 2442-7586.

Wierzbicka Anna. 1996. Semantics: Prime and Universal. Oxford: Oxford University

\section{Acknowledgments}

In this opportunity the authors would like to address our greatest thanks to those who have given valuable contribution to this research so that it can be publicized through this publication. My great gratitude delivers to my family and friends who always being my support system team. Also for the editorial board and contact person of this publication, thank you for the time and help in editing this research so that this research will be worthwhile to the development of semantic studies. 